\title{
Technical Efficiency of Smallholder Tea Production in South-Eastern Malawi: A Stochastic Frontier Approach
}

\author{
Fexter Katungwe $^{1 *}$, Gabriel Elepu ${ }^{1}$ and Joseph Dzanja ${ }^{2}$
}

Received: $15^{\text {th }}$ December 2017/ Accepted: $22^{\text {nd }}$ June 2017

\begin{abstract}
Tea production contributes $8.8 \%$ of foreign exchange earnings in Malawi. A study was undertaken in South-Eastern Malawi to understand the smallholder tea production system, estimate its technical efficiency and establish sources of technical inefficiency. A multi-stage sampling technique was employed to select 230 smallholder tea farmers, who participated in the study. Data analysis was done using SPSS and STATA. Smallholder tea production was characterised using descriptive statistics. A Cobb-Douglas Stochastic frontier model and Tobit Regression model were run in STATA to determine technical efficiency and sources of technical inefficiency respectively. The study found that the technical efficiency of smallholder tea farmers ranged from $16 \%$ to $92 \%$ with a mean of $67 \%$. Education, distance to factory and farming experience significantly reduced technical inefficiency at 1\%, 5\% and 10\% level respectively; and inefficiency was relatively low among farmers that utilised hired labour, and high among those that were contracted by government cooperative. Access to non-tea income was not a source of technical inefficiency. The findings of the study imply that various policies on extension and training have to be implemented to increase the knowledge of the smallholder tea farmers to ensure increased technical efficiency. Smallholder tea farmers should also be facilitated to access labour-saving technologies to enable them carry out timely farm operations.
\end{abstract}

Keywords: Tea, smallholder, technical efficiency

\section{INTRODUCTION}

Malawi is among the top 20 producers of tea in the world and, it is the second largest tea producer in Africa after Kenya (FAOSTAT, 2012). Tea has traditionally been the second foreign exchange earner after tobacco but its significance has been declining from $21.2 \%$ in the 1970 s to $8.8 \%$ in the late 2000 s (Chirwa et al., 2005). Malawi exports about $95 \%$ of total amount of tea produced in the country (International Tea Committee, 2013); and takes about $3 \%$ share of world tea export market (www.tea.co.uk).

Malawi was the first country in Africa to grow tea on a commercial scale, which started at Mulanje in the 1880 s. Tea is grown in three districts namely Mulanje and Thyolo in
Southern region and Nkhata-Bay in the North. According to Fairtrade (2010), large commercial estates account for $93 \%$ of tea production, with the remaining $7 \%$ contributed by smallholder farmers. Currently, there are about 15,000 smallholder tea farmers in Malawi cultivating about 4,000 hectares. Every smallholder farmer belongs to one of the five outgrower trusts or associations. The farmers cultivate tea on small plots of land with an average holding size of less than a half hectare (Fairtrade, 2010). Consequently, it becomes imperative that farmers should make use of available inputs to produce at optimum levels in order to meet their income and food security needs. 
According to World Bank (2004), smallholder tea sector production in Malawi has an average yield of 1,049 kilograms (of made tea) per hectare. This yield is far much lower than the average yield of 2,465 kilogrammes per hectare achieved by estates. This is also comparably lower than the yield of 1,849 kilogrammes realised by fellow smallholder tea farmers in Kenya. And it is about one-third of on-farm yield of 3,669 kilogrammes obtainable when old bushes are replanted with improved clonal varieties. This research was therefore designed to investigate the factors that prevent the smallholder farmers in Thyolo and Mulanje districts from realising their potential outputs.

The study was undertaken to determine the technical efficiency of smallholder tea production in South-Eastern Malawi and identify sources of technical inefficiency. It was hypothesized that smallholder tea farmers in South-Eastern Malawi are technically efficient due to factors such as tea-farming experience, education and access to off-farm income by the smallholder tea farmer. The findings of this study would be of importance to policy makers in smallholder tea subsector namely Tea Association of Malawi (TAML), tea estate companies, Tea Research Foundation of Central Africa, smallholder tea trusts and Ministry of Agriculture.

\section{MATERIALS AND METHODS}

The study was conducted in South-Eastern Malawi in the districts of Mulanje and Thyolo. These districts were purposively selected since they are major tea-growing areas in Malawi, and this is where smallholder tea production is practised. Mulanje is one of the 28 districts of Malawi and it is located at the longitude of 35.51 and latitude of -15.99 . It has an average elevation of $640 \mathrm{~m}$ above sea level and has an annual rainfall of 1,200 and $1,500 \mathrm{~mm}$ per annum (www.trfca.net/central.html). The district is the biggest producer of both estate and smallholder tea in Malawi. Thyolo district is located at -16.0703 latitude and 35.1471 longitude. The average elevation of Thyolo is 952 meters (Thyolo District Assembly, 2009). Both areas are hilly in topography and hosting mountain ranges of Mulanje and Thyolo.

Smallholder tea farmers were selected for interviews in this survey using a multi-stage sampling technique. A list of all outgrower trusts was obtained from Tea Research Foundation of Central Africa (TRFCA). Information on membership and land size under cultivation was obtained from the outgrower trust leaders in both districts to provide the sampling frame. There were 12,199 and 2,739 smallholder tea farmers in Mulanje and Thyolo districts respectively giving a total of 14,938 farmers.

A proportionate-to-size sampling procedure was employed to come up with a sample at district and outgrower trust levels. There were five outgrower trusts and were purposively selected for sampling in both districts. Under each trust, a simple random sampling technique was done to come up with Smallholder Tea Authority (STA) blocks to be sampled. Where more than one trust shared a catchment area, effort was made to sample different blocks for each trust.

A total of 22 blocks were sampled for this survey; 15 blocks were from Mulanje district, while 7 were from Thyolo. More than one village was selected where the required sample from a given block was more than seven farmers, and one village was selected where the required sample from that block was less than seven. From each selected village, a simple random sampling technique was used to select smallholder tea farmers for the study. Consequently, a sample of 187 smallholder tea farmers was drawn from Mulanje district, while a sample of 43 farmers was drawn from Thyolo giving a total of 230 farmers. Cross-sectional data were collected using a semi-structured questionnaire in months of May and June 2012. Additional information 
was obtained from TRFCA and outgrower trusts.

The analyses were done by making use of STATA and SPSS computer packages. The smallholder tea production system was characterised using descriptive statistics. Further, the study assumed that tea output in kilogrammes was dependent on farm size under tea cultivation (ha), amount of pesticides applied (litres), amount of fertilizer applied (kg), cost of human labour deployed (MK), amount of capital invested in implements (Malawi Kwacha) and tea type ( $1=$ clonal tea, 0 otherwise) and age of tea.

The following stochastic frontier production function was estimated as proposed by Aigner et al. (1977) and Meeusen and Van Den Broeck (1977) and used by Adedeji et al. (2011) and Amos (2007).

$\ln Y_{i}=\beta_{0}+\beta_{1} \ln X_{1}+\beta_{2} \ln X_{2}+\ldots \ldots+\beta_{8} \ln X_{8}+V_{i}-U_{i}$

Where subscript $i$ refers to the observation of the $i^{\text {th }}$ farmer, and

$Y=$ Tea Production $(\mathrm{kg})$

$X_{1}=$ labour cost $(\mathrm{Mk})$

$X_{2}=$ Cost of implements (Mk)

$X_{3}=$ Land size (ha)

$X_{4}=$ Fertilizer amount $(\mathrm{kg})$

$X_{5}=$ Age of Tea bushes (Years)

$X_{6}=$ Pesticide amount (litres)

$X_{7}=$ Lime amount $(\mathrm{kg})$

$X_{8}=$ Type of tea (clonal tea $=1,0$ otherwise)

$\beta_{i}{ }^{\prime} \mathrm{s}=$ the parameters to be estimated

$\ln =$ natural logarithms

$V_{i}=$ the two-sided, normally distributed

random error
$U_{i}=$ the one-sided inefficiency component with a half-normal distribution.

The farm specific technical efficiency (TE) of the $i$ th farmer was estimated using the expectation of $U_{i}$ conditional on the random variable $\left(\boldsymbol{X}_{\mathrm{i}}\right)$ as shown by Battese and Coelli (1995). According to Tadesse and Krishnamoorthy (1997), the TE of an individual farmer is defined in terms of the ratio of the observed output to the corresponding frontier output given the available technology, that is:

$T E=\frac{Y_{i}}{Y^{*}{ }_{i}}=\frac{f\left(X_{i} ; \beta\right) \exp \left(V_{i}-U_{i}\right)}{f *\left(X_{i} ; \beta\right) \exp V_{i}}=\exp \left(-U_{i}\right)$

Where, $\boldsymbol{Y}_{\boldsymbol{i}}=$ observed output and $\boldsymbol{Y}_{\boldsymbol{i}}^{*}$ is the frontier output so that TE is between 0 and 1 .

Sources of technical inefficiency were determined by examining the relationship between technical inefficiency $\left(U_{i}\right)$ and the farm characteristics in the two-limit Tobit Regression function (Binam et al., 2005). This study estimated the Tobit regression function for determinants of technical inefficiency as follows.

$U_{i}=\delta_{0}+\delta_{1} Z_{1 i}+\delta_{2} Z_{2 i}+\cdots+\delta_{9} Z_{9 i}$

Where: $U_{i}=$ technical inefficiency of the ith smallholder tea farmer

$\delta_{i}=$ is a vector of parameters $(i=1,2, \ldots, 9)$

$Z_{1}=$ Age of farmer (yrs)

$Z_{2}=$ household size (number)

$Z_{3}=$ Educational level (years of schooling)

$Z_{4}=$ Age of tea bushes (years)

$Z_{5}=$ Occupation (None-tea income $=1,0$ otherwise)

$Z_{6}=$ Extension contact (number of visits) 
$Z_{7}=$ Type of contract (estates $=1,0$ otherwise)

$Z_{8}=$ Type of tea (Clonal tea $=1,0$ otherwise)

$Z_{9}=$ Hired labour $($ Yes $=1,0$ otherwise $)$

\section{RESULTS AND DISCUSSION}

\section{Characteristics of Smallholder Tea Farmers in South-Eastern Malawi}

This study found that a typical smallholder tea farmer was 48 years old, had a six-member household, attended an average of five years of formal education, had a 19-year tea farming experience and managed a 30 -year old plantation, which was 0.4 ha in size. On average, the farmer applied $347 \mathrm{~kg}$ of inorganic fertilizer and $61 \mathrm{~kg}$ of lime per hectare. The farmer needed MK6,733 for purchasing and maintaining farm implements such as hoes, panga knives, bamboo baskets, polythene bags and pruning knife. The farmer was visited by an extension worker ten times in a year. Despite the release of improved (clonal) varieties of tea by Tea Research Foundation of Central Africa (TRFCA), only $37 \%$ of the farmers had pure stands of such varieties. The survey found that $33 \%$ of the farmers used family labour only and $3 \%$ used hired labour only; and $63 \%$ of the farmers used both family and hired labour. Located nine kilometres away from the processing factory, the smallholder farmer sold 7,938 kilogrammes of greenleaf (about 1,746 $\mathrm{kg}$ made tea) in 2010/11 season. Assessing the proportions, it was found that $62 \%$ of the farmers had tea as the only source of income, while the remainder had other sources of income. Lujeri Tea Estate and Eastern Produce Limited bought over $75 \%$ of smallholder greenleaf tea. STECO, a government-owned cooperative, bought about $19 \%$. The estates of Makandi and Satemwa in Thyolo bought a meagre $5 \%$ of smallholder green leaf. Refer to Table 01 for selected descriptive characteristics of smallholder tea production in South-Eastern Malawi.

\section{Estimation of Technical Efficiency}

\section{Estimation of Elasticity of Production and Returns to Scale}

There was need to estimate an Ordinary Least Squares (OLS) function to help determine the elasticity of production that would indicate whether farmers were operating at optimum level or had room for improvement. Prior to that, the variables in the function were tested for multicollinearity and heteroskedasticity. For multicollinearity, variance inflation factor (vif) was $1.86<10$ indicating tolerable levels of multicollinearity and implying that the variables were fit to be used in the model. Breusch-Pagan/Cook-Weisberg test was used to test for heteroscedasticity. The model had a chi-square value of 16.89 hence rejecting the null hypothesis that the variances were constant at $1 \%$ level of significance. This led to adopting the alternative hypothesis that the variances were not equal. An OLS regression model was then run with robust standard errors to check for existing heteroscedasticity. Adding the parameters for the regressed independent variables in the model, it was found that the returns to scale was 1.906 indicating increasing returns to scale and that tea production was in stage I of the production function. According to Kolawole and Ojo (2007), such outcome shows that proportionate increase of the inputs could increase output by a relatively greater proportion. According to Adedeji et al. (2011), it can further be inferred that optimum efficiency of production had not yet been achieved and the technologies for tea production were underutilized below the maximum technical efficiency. This implies that policy makers should formulate policies that could induce farmers to efficiently utilise the available resources so that tea could become a more productive and profitable enterprise. The results from the model suggest that tea production was significantly affected by investment in labour, amount of fertilizer applied, the age of tea bushes, amount of pesticides applied and type of tea as indicated in Table 02 . 
Table 01: Characteristics of Smallholder Tea Producers in Malawi

\begin{tabular}{cccc}
\hline Variable & Units & Sample Mean & Std. Dev. \\
\hline Education level & Years & 5 & 4 \\
Age of Tea Bushes & Years & 30 & 14 \\
Household Size & Number & 6 & 2 \\
Experience & Years & 19 & 14 \\
Land Size & hectares & 0.4 & 0.44 \\
Fertilizer & $\mathrm{Kg} / \mathrm{ha}$ & 347 & 193 \\
Pesticides & Litres/ha & 0.09 & 0.5 \\
Lime & $\mathrm{Kg} / \mathrm{ha}$ & 61 & 156 \\
Implements Cost & $\mathrm{Mk} / \mathrm{ha}$ & 7820 & 9400 \\
Labour cost & $\mathrm{Mk} / \mathrm{ha}$ & 72128 & 52848 \\
Distance to factory & $\mathrm{Km}$ & 9 & 11 \\
Extension & $\mathrm{Visits} / \mathrm{yr}$ & 10 & 10 \\
Greenleaf Output & $\mathrm{Kg} / \mathrm{ha} / \mathrm{yr}$ & 7938 & 7033 \\
\hline
\end{tabular}

Source: Survey Data, 2012

Table 02: Estimates of the Cobb-Douglas OLS Model for Smallholder Tea Production in South Eastern Malawi (Dependent Variable: Ln Production Kg)

\begin{tabular}{cccc}
\hline Variable & Parameter & Robust S.E & $\mathrm{t}$ \\
\hline Constant & $-2.866^{* * *}$ & 0.0 .076 & -4.03 \\
Ln Labour Cost & $0.898^{* * *}$ & 0.08 & 11.24 \\
Ln Implements Cost & -0.061 & 0.044 & -1.37 \\
Ln Land Size & 0.029 & 0.066 & 0.44 \\
Ln Fertilizer amount & $0.212^{* * *}$ & 0.07 & 3.03 \\
Ln Age of Tea Bushes & $0.311^{* * *}$ & 0.059 & 5.25 \\
Ln Pesticide amount & $0.387^{* *}$ & 0.176 & 2.2 \\
Ln Lime amount & -0.002 & 0.018 & -0.13 \\
Type of Tea (Clonal tea $=1)$ & $0.132^{*}$ & 0.076 & 1.75 \\
\hline
\end{tabular}

$F(8,221)=101.69$, Prob $>F=0.0000, R^{2}=0.7569$, Root $M S E=0.54913$

$* * *, * *, *$ mean significant at $1 \%, 5 \%$ and $10 \%$ respectively

Source: Survey Data, 2012

The computed coefficients for the regressed inputs suggest that $1 \%$ increase in the cost of labour would generate $0.898 \%$ increase in greenleaf output, while $1 \%$ increase in fertilizer amount would yield $0.212 \%$ increase in greenleaf output. Apart from that, letting the tea bush grow one more year would enable the farmer to realise $0.311 \%$ increase in greenleaf production. Replacing natural log of tea age with natural log of its square, it was found that the coefficient reduced to 0.157 . This implies that as tea bush grows older, its greenleaf output diminishes. Furthermore, a 1\% increase in pesticide application would lead to $0.387 \%$ increase in greenleaf output. Finally, the farmers that grew clonal tea would produce $0.132 \%$ more greenleaf when compared to those that had seedling tea. 


\section{Estimation of Stochastic Production Frontier}

A Cobb-Douglas stochastic production frontier model was estimated using STATA software. The continuous variables were transformed into log linear form before running them in the model. The dependent variable of the estimated model was greenleaf output in kilogrammes and the independent variables included size of land under cultivation in hectares, type of tea (clonal tea $=1,0$ otherwise), amount of fertilizer applied in kilogrammes, cost of labour in Malawi Kwacha, amount of pesticides applied in litres, amount of lime applied in kilogrammes, cost of implements in Malawi Kwacha and age of tea in years. The existence of inefficiency component in the stochastic frontier model for smallholder tea farmers was tested using likelihood-ratio test. A null hypothesis that there were no inefficiencies in the model (Ho: sigma_u=0) was rejected at $5 \%$ level as shown in Table 03 .

This implied that the inefficiency variation (sigma_u) was significantly different from zero hence worth measuring. It further implied that the frontier was not deterministic but rather stochastic in nature. This finding led to rejection of the null hypothesis and concluded that smallholder tea farmers in South-Eastern Malawi are not technically efficient.

The maximum likelihood estimates indicated that labour cost, fertilizer amount and age of tea bushes significantly and positively contributed to the frontier production at $1 \%$ level; while pesticide amount significantly contributed at $10 \%$ level. The observed positive effect of labour was in agreement with recent studies by Mapemba et al. (2013), Yuya (2014) and Asante et al. (2014). The positive effect of fertilizer on production was in line with Adeoye et al. (2014), Abu (2011) and Gharderzadeh and Rahimi (2008). The significantly positive effect of age of tea bushes is consistent with the findings of Danso-Abbeam et al. (2012) and Ojo and Ehinmowo (2010) among coffee and Kolanut farmers respectively. The positive effect for pesticide application was also found by Egbetokun and Ajijola (2008) among cowpea farmers in Nigeria, and Piya et al. (2012) among rice farmers in Nepal.

Table 03: Maximum Likelihood Estimates from the Cobb-Douglas Stochastic Frontier Model for Smallholder Tea Production in (Dependent Variable: Ln Production Kg)

\begin{tabular}{cccc}
\hline Variable & Parameter & S.E & Z \\
\hline Constant & $-1.997 * *$ & 0.682 & -2.93 \\
Ln Labour Cost & $0.864 * * *$ & 0.068 & 12.66 \\
Ln Implements Cost & -0.058 & 0.05 & -1.18 \\
Ln Land Size & 0.043 & 0.063 & 0.68 \\
Ln Fertilizer Amount & $0.213^{* * *}$ & 0.062 & 3.42 \\
Ln Age of Tea Bushes & $0.289 * * *$ & 0.057 & 5.06 \\
Ln Pesticide Amount & $0.376^{*}$ & 0.212 & 1.78 \\
Ln Lime amount & -0.008 & 0.02 & -0.38 \\
Type of tea $($ Clonal Tea $=1)$ & 0.097 & 0.087 & \\
Sigma_v $\left(\sigma_{\mathrm{v}}\right)$ & 0.412 & 0.049 & \\
Sigma_v $\left(\sigma_{\mathrm{u}}\right)$ & 0.57 & 0.104 & \\
Sigma squared $\left[\sigma^{2}=\sigma_{\mathrm{v}}^{2}+\sigma_{\mathrm{u}}^{2}\right]$ & 0.495 & 0.091 & \\
Lambda $\left[\lambda=\left(\sigma_{\mathrm{u}} / \sigma_{\mathrm{v}}\right)\right]$ & 1.384 & 0.145 & \\
\hline
\end{tabular}

LL: -177.6645 Likelihood-ratio test of sigma_u=0: chibar $2(01)=4.16 \quad$ Prob $>=$ chibar $2=0.021$

${ }^{* * *},{ }^{* *}, *$ mean significant at $1 \%, 5 \%$ and $10 \%$ respectively

Source: Survey data 2012 


\section{Determining Technical Efficiency}

Upon obtaining the Maximum Likelihood estimates from the Cobb-Douglas Stochastic Frontier model, the farm-level technical efficiency scores were predicted. It was found that smallholder tea farmers in Malawi had an average technical efficiency of $67 \%$ with the least efficient farmer obtaining a score of $16 \%$ while the most efficient farmer scoring $92 \%$. Considering the computed mean, it was inferred that smallholder tea farmers in Malawi had a possibility of increasing their greenleaf output by $33 \%$ if their efficiency at utilizing the available technology was improved. Basing on the range of the predicted levels of technical efficiency, it was inferred that there was a wide disparity in technical efficiency amongst smallholder tea farmers. This implied that there was room for the increase in tea output; and could be achieved through efficient use of the existing technologies without necessarily introducing the new ones.

The computed mean technical efficiency of this survey was lower compared to the technical efficiency of $83.1 \%$ observed by Basnayake and Gunaratne (2002) in the Tea Smallholding
Sector of Sri Lanka. It was also lower when compared to efficiency levels of other plantation crop producers such as Nigerian cocoa farmers, who Amos (2007) and Adedeji et al. (2011) found that they were $72 \%$ and $97 \%$ technically efficient respectively. Furthermore, it was lower when compared to the technical efficiency of $89.6 \%$ observed by Nchare (2007) among coffee farmers in Cameroon. But the finding is similar to the finding of Dhehibi (2007) who noted that the Palm-Oil Growing sector in Tunisia was $64.34 \%$ technically efficient. However, all these studies agree that smallholder farmers of plantation crops are not technically efficient.

It was also observed that $60 \%$ of the farmers operated above the mean technical efficiency of $67 \%$, and only $47.8 \%$ operated above the technical efficiency of $70 \%$. Further analysis revealed that the highest proportion of smallholder tea farmers falls within the technical efficiency category of $71-80 \%$, while the smallest falls under $91-100 \%$ as shown in Figure 01 . These findings imply that policy on smallholder tea farming should shift towards improving the technical efficiency of farmers in order to increase smallholder tea production.
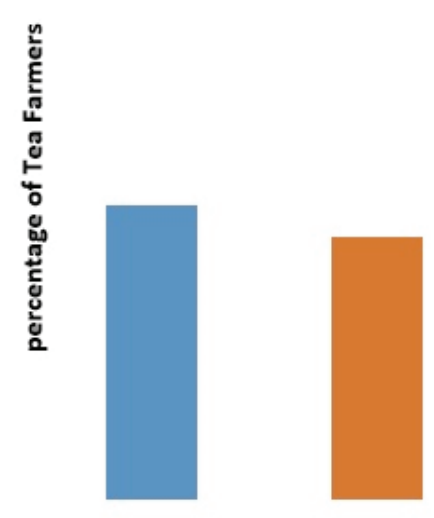

Source: Survey 2012
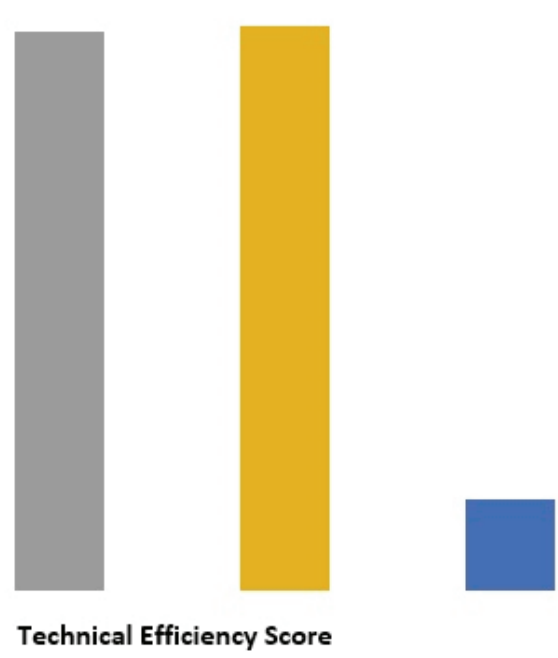

Technical Efficiency Score

Figure 01: Percentage Distribution of Tea Farmers against Technical Efficiency Scores 


\section{Sources of Technical Inefficiency}

Upon predicting the farm-level technical efficiency levels from the Cobb-Douglas Stochastic Frontier model, the inefficiency score $\left(U_{i}\right)$ was also predicted for each farmer. Referring to Equation (3), $U_{i}$ was regressed against the farm characteristics namely tea farming experience in years, household size as number of individuals per household, education in years of schooling, distance from farm to factory in kilometres, extension as number of visits per year, type of contract (Govt. cooperative $=1,0$ otherwise), occupation (nontea income $=1,0$ otherwise), access to hired labour (yes $=1,0$ otherwise) as shown in Tobit Regression Model shown in Table 04.

The results showed that the Chi-square value was significant at $1 \%$ level implying that the variation in the inefficiency was significantly explained by the independent variables included in the Tobit regression model. It was then found that education was the most important socioeconomic factor as it reduced technical inefficiency at $1 \%$ level of significance. The negative sign for this variable means that if the household head spent extra year in formal education, technical inefficiency of that household would significantly reduce by $0.013 \%$. This result agrees with the findings of Maganga (2012), Adedeji et al. (2011), Wakili (2012) and Kalibwani et al. (2014).

The second most important socio-economic factor was distance to the factory, which was significant at 5\%. Its negative coefficient means that if distance from tea farm to tea-processing factory increased by one kilometre, inefficiency would decrease by $0.003 \%$. This finding is in line with that of Nto and Mbanasor (2011), who found that nearness to market negatively affected productivity of agribusiness firms in Nigeria.

The other equally important factor was type of contract. The positive coefficient on type of contract implies that smallholder tea growers that had a contract with a government cooperative had relatively higher technical inefficiency when compared to those who had contracts with estate-managed trusts. This is in agreement with Chirwa and Kydd (2005), who attributed the higher productivity of estatecontracted farmers in the same region to more contacts with their extension workers.

Table 04: Sources of Technical Inefficiency in Smallholder Tea Production of South-Eastern Malawi as Estimated from Tobit Regression Function (Dep. Var: Inefficiency, $U_{i}$ )

\begin{tabular}{cccc}
\hline Source of TE & Coefficient & S.E & $\mathrm{t}$ \\
\hline Constant & $0.6^{* * *}$ & 0.005 & 11.52 \\
Experience (years of tea farming) & $-0.002^{*}$ & 0.001 & -1.84 \\
Household Size (number) & -0.006 & 0.006 & -1.1 \\
Education (years) & $-0.013^{* * *}$ & 0.004 & -3.24 \\
Distance from farm to factory $(\mathrm{km})$ & $-0.003^{* *}$ & 0.001 & -2.17 \\
Occupation (Non-tea income=1) & 0.044 & 0.027 & 1.59 \\
Extension (number of visits) & 0.002 & 0.001 & 1.21 \\
Type of Contract (Govt. Coop=1) & $0.101^{* *}$ & 0.039 & 2.57 \\
Access to hired labour (yes $=1$ ) & $-0.056^{*}$ & 0.029 & -1.94 \\
\hline
\end{tabular}

$* * *, * *, *$ mean significant at $1 \%, 5 \%$ and $10 \%$ respectively

LR Chi ${ }^{2}(9)=26.70$, Prob $>\mathrm{Chi}^{2}=0.0008$, Log likelihood $=32.4048$

Source: Survey 2012 
Access to hired labour and tea farming principles and solve the recurrent problems. experience were least significant at $10 \%$. The dummy for access to hired labour had a negative coefficient implying that those who utilized it had a relatively low inefficiency level than those that did not. This finding was consistent with those of Ashaolu et al. (2010) and Abatania et al. (2012). This implies that, though family labour is in ready supply in South-Eastern Malawi, supplementary hired labour especially in peak season and pruning times yielded significant returns. For instance, in rainy season, use of hired labour enables the farmer to timely undertake crucial tasks such as picking, weeding and fertilizer application.

Coefficient for tea farming experience was significant and negative in consistence with the findings of Ogundele and Okoruwa (2006) and Onumah et al. (2010), who found that farming experience significantly affected technical efficiency of rice farmers in Nigeria and fish farmers in Ghana respectively. The coefficient and its sign meant that if the teafarming experience were increased by one year, the smallholder farmer's inefficiency would decrease by $0.002 \%$. This finding entails that the accrued farming experience enabled the farmers to competently apply the production

\section{CONCLUSIONS AND RECOMMENDATIONS}

Following the study findings, it can be generally concluded that smallholder tea farmers in South-Eastern Malawi are technically inefficient operating at a technical efficiency range of $16 \%$ to $92 \%$, and a mean of $67 \%$. Smallholder tea production is significantly affected by labour cost, fertilizer amount, tea age and pesticide amount used. Technical inefficiency decreases with household years of formal education, distance from farm to factory, contract arrangements with private estates, utilization of hired labour and farming experience. The study established that access to off-farm income is not a source of technical inefficiency. The implication of the findings is that policies should be directed towards improving smallholder farmer's knowledge in modern tea production techniques, developing labour-saving technologies, and formulating conducive greenleaf-buying contracts to increase their contribution and economic returns along the value chain.

\section{REFERENCES}

Abatania, L.N., Hailu, A. and Mugera, A.W. 2012. Analysis of farm household technical efficiency in Northern Ghana using bootstrap DEA. Paper presented at the 56th annual conference of the Australian Agricultural and Resource Economics Society. The Esplanade Hotel, Fremantle WA, 7-10 February 2012. DOI: http://dx.doi.org/10.1111/j.1467-8489.1981.tb00396.x

Abu,O. 2011. Fertilizer Usage and Technical Efficiency of Rice Farms under Tropical Conditions: A Data Envelopment Analysis (DEA). Journal of Agricultural Science 2(2): 83-87 DOI: http://dx.doi.org/10.5539/jas.v5n9p37

Adedeji, I.A., Ajetomobi, J.O and Olapade-Ogunwole, F. 2011. Technical Efficiency of Cocoa Production in Oyo State, Nigeria. Continental J. Agricultural Economics 5 (1): 30 - 40. DOI: http://dx.doi.org/10.5707/cjae.2012.6.1.10.16

Adeoye, I.B., Fashogbon, A.E. and Idris, A.B. 2014. Analysis of Technical Efficiency of Pepper Production among Farmers under Tropical Conditions. International Journal of Vegertable Science. Vol. 20(2). DOI: http://dx.doi.org/10.1080/19315260.2012.762964 
Aigner, D.J. and Chu, S.F. 1968. On Measuring the Industry Production Function”.American Economic Review 58 (4). 826-839. DOI: http://dx.doi.org/10.2307/1056677

Aigner, D.J., Lovell, C.A.K. and Schmidt, P. 1977. Formulation and Estimation of Stochastic Frontier Production Function Models. Journal of Econometrics, 6, 21-37. DOI: http:// dx.doi.org/10.1016/0304-4076(77)90052-5

Amos T. T. 2007. An Analysis of Productivity and Technical Efficiency of Smallholder Cocoa Farmers in Nigeria. Journal of Social Science, 15(2): 127 - 133. DOI: http://dx.doi. org/10.15405/epsbs.2016.08.97

Asante, B.O., Wiredu, A.N., Martey, E., Sarpong, D.B. and Mensah-Bonsu, A. 2014. Nerica Adoption and Impacts on Technical Efficiency Rice Producing Households in Ghana: Implications for Research and Development. American Journal of Experimental Agriculture. 4(3):244-262. DOI: http://dx.doi.org/10.9734/ajea/2014/7250

Ashaolu, O.F., Momoh, S. Ayinde, I.A. and Ugalahi, U.B. 2010. Analysis Of Resource-Use Efficiency in Beniseed Production in Obi And Doma Local Government Areas of Nassarawa State, Nigeria. Journal of Humanities, Social Sciences and Creative Arts. DOI: http://dx.doi. org/10.14738/assrj.42.2490

Basnayake, B. M. J. K., and Gunaratne, L. H. P. 2002. Estimation of Technical Efficiency and its Determinants in the Tea Small Holding Sector in the Mid Country Wet Zone of Sri Lanka. Sri Lanka Journal of Agricultural Economics 4: 137-150. DOI: http://dx.doi.org/10.4038/ sjae.v4i0.3488

Battese, G.E. and Coelli, T.J. 1995. A Model for Technical Inefficiency Effect in Stochastic Frontier Production for Panel Data. Empirical Economics, 20: 325-345. DOI: http://dx.doi. org/10.1007/bf01205442

Binam, J.N., Tonye, J. and Wandji, N. 2005. Source of Technical Efficiency among Smallholder Maize and Peanut Farmers in the Slash and Burn Agriculture Zone of Cameroon. Journal of Economic Cooperation 26,1. 193-210. DOI: http://dx.doi.org/10.1016/j.foodpol.2004.07.013

Chirwa, E. W., and Kydd, J. G. 2005. Study on Farmer Organizations in Smallholder Tea in Malawi. Report of the Farmer Organisations and Market Access Study. London: Imperial College. DOI: http://dx.doi.org/10.1093/acprof:oso/9780199689347.003.0007

Danso-Abbeam1, G., Aidoo, R., Agyemang K.O. and Ohene-Yankyera, K. 2012. Technical efficiency in Ghana's cocoa industry: Evidence from Bibiani-Anhwiaso-Bekwai District. Journal of Development and Agricultural Economics Vol. 4(10), pp. 287-294. http:// www.academicjournals.org/JDAE. DOI: 10.5897/JDAE12.052 ISSN 2006- 9774 C2012 Academic Journals. DOI: http://dx.doi.org/10.5897/jdae12.052

Dhehibi, B., Lachaal, L., Karray B., and Chebil, A. 2007. Decomposition of Output Growth in the Tunisian Olive-Growing Sector: A Frontier Production Function Approach. Economic Research Working Paper No 87. African Development Bank. DOI: http://dx.doi. org/10.1080/16507540701597113 
Egbetokun, A.O., AND Ajijola, S. 2008. Technical Efficiency of Cowpea Production in Osun State Nigeria. Continental Journal of Agricultural Economics 2:32-37. Wilolud Online Journals. DOI: http://dx.doi.org/10.1016/s0313-5926(10)50006-7

Fairtrade. 2010. Fairtrade Tea: Early Impacts in Malawi. Impact Briefing Paper, June 2010. Fairtrade Foundation. DOI: http://dx.doi.org/10.1057/9781137284518.0011

FAOSTAT 2012. Food and Agriculture Organisation, Rome, Italy. DOI: http://dx.doi.org/10.1002/ pad.4230050313

Ghaderzadeh, H. and Rahimi, M.H. 2008. Estimation of Technical Efficiency of Wheat Farms "A Case Study in Kurdistan Province, Iran” American-Eurasian J. Agric. \& Environ. Sci., 4 (1): 104-109, ISSN 1818-6769 (C) IDOSI Publications. DOI: http://dx.doi.org/10.1002/jsfa.3975

International Tea Committee, 2013. DOI: http://dx.doi.org/10.1163/1570-6664_iyb_sim_ org_38818

Kalibwani, T.M., Mutenyo, J. and Kato, E. 2014. Technical Efficiency of Farming Households in Uganda: Evidence from the National Panel Survey Data 2005-2010. Research Journal of Agriculture and Environmental Management. Vol. 3(8). pp 380-392. DOI: http://dx.doi. org/10.1596/1813-9450-6942

Kolawole, O. and Ojo, S.O. 2007. Economic Efficiency of Small Scale Food Crop Production in Nigeria: A Stochastic Frontier Approach. Kamla-Raj 2007 J. Soc. Sci., 14(2): 123-130. DOI: http://dx.doi.org/10.4314/joafss.v7i1.60301

Maganga, A.I. 2012. Technical Efficiency and its Determinants in Irish Potato Production: Evidence from Dedza District, Central Malawi. American-Eurasian J. Agric. \& Environ. Sci., 12 (2): 192-197. ISSN 1818-6769. DOI: http://dx.doi.org/10.5897/ajar11.1463

Mapemba, L.D., Maganga, A.M. and Mango, N. 2013. Farm Household Production Efficiency in Southern Malawi: An Efficiency Decomposition Approach. Journal of Economics and Sustainable Development. Vol. 4 (3). DOI: http://dx.doi.org/10.1007/978-0-387-98176-5_7

Meeusen, W., and Broeck, J.V.D. 1977. Efficiency Estimation from Cobb- Douglas Production Functions with Composed Error. International Economics Review, Vol.18, No.2, 435-444. DOI: http://dx.doi.org/10.2307/2525757

Nchare, A. 2007. Analysis of factors affecting the technical efficiency of Arabica coffee producers in Cameroon. African Economic Research Consortium, Nairobi. DOI: http://dx.doi. org/10.4314/ajep.v12i1.24250

Nto, P.O.O. and Mbanasor. 2011. Productivity in Agribusiness Firms and its Determinants in Abia State, Nigeria. Journal of Economics and International Finance. Vol 3 (12), pp. 662-668. DOI: http://dx.doi.org/10.4314/naj.v39i1.3259

Ogundele, O.O and Okoruwa, V.O. 2006. Technical efficiency differentials in rice production technologies in Nigeria. AERC Research Paper 154. African Economic Research Consortium, Nairobi. DOI: http://dx.doi.org/10.4314/ajep.v11i1.24261 
Ojo, S. O. and Ehinmowo, O. O. 2010. Economic Analysis of Kola-nut Production in Nigeria. Kamla-Raj 2010 J Soc Sci, 22(1): 1-5 (2010). DOI: http://dx.doi.org/10.4314/naj.v29i1.49309

Onumah, E.E., Brumer, B. and Horstgen-Schwark, G. 2010. Productivity of Hired and Family Labour and Determinants of Technical Inefficiency in Ghana's Fish Farms. Journal of Agricultural Economics-Czech, 56, 2010 (2), 79-88. DOI: http://dx.doi.org/10.1111/j.17497345.2010.00391.x

Piya, S. Kiminami, A. and Yagi, H. 2012. Comparing the Technical Efficiency of Rice Farms in Urban and Rural Areas: A Case Study from Nepal. Trends in Agricultural Economics 5(2):48-60. ISSN 19947933/DOI 10.3923/tae.2012.48.60. DOI: http://dx.doi.org/10.3923/ tae.2012.48.60

Tadesse, B. and Krishnamoorthy, S. 1997. Technical Efficiency in Paddy Farms of Tamil Nadu. An Analysis based on Farm Size and Ecological Zone. Journal of Agricultural Economics. Vol. 16. Issue 3. Pages 185-192. DOI: http://dx.doi.org/10.1016/s0169-5150(97)00004-2

Thyolo District Assembly Socio-economic Profile 2006-2009. DOI: http://dx.doi.org/10.15406/ mojph.2016.04.00096

Wakili, A.M. 2012. Technical Efficiency of Sorghum Production in Hong Local Government Area of Adamawa State, Nigeria. Russian Journal of Agricultural and Socio-Economic Sciences, No. 6(6). DOI: http://dx.doi.org/10.18551/rjoas.2012-06.02

World Bank. 2004. Integrated Framework. Diagnostic Trade Integration Study-.Malawi. Volume 1 DOI: http://dx.doi.org/10.1596/24665

www.tea.co.uk

www.trfca.net/central.html

Yuya, B.A. 2014. Comparative Analysis of Technical Efficiency of Smallholder Irrigated and Rainfed Farm Production: The Case of Girawa District, Oromia, Ethiopia. Journal of Agricultural Economics, Extension and Rural Development. Vol. 2(5), pp 054-062. DOI: http://dx.doi. org/10.5337/2011.202 